\title{
気泡コンクリート壁体材料内の結露・再蒸発過程の 水分挙動に関する研究 \\ MOISTURE BEHAVIOUR IN WALL MATERIAL MADE OF CELLULAR CONCRETE UNDER CONDENSATION AND RE-EVAPORATION PROCESS
}

\author{
寺 島 貴根*，水畑雅行** \\ Takane TERASHIMA and Masayuki MIZUHATA
}

\begin{abstract}
The purpose of this study is to understand quantitative properties of internal condensation in porous material. In winter, water vapor is generally supplied from the interior side of a roof slab and the condensed water accumulated at this side, causes difficulties. In this paper the moisture behavior in this process is dealt with. Firstly the properties of materials concerned with moisture transfer are discussed. Next the experiment and the analysis of the condensation and re-evaporation process are discussed. And the effects of variations in properties on the analysis is also discussed. Consequently, the validity of the application of the simultaneous heat and moisture transfer equation to the analysis of the internal moisture content is shown. Finally it is proved that the variance of material properties effects on the results of the internal moisture content calculation to a large degree.
\end{abstract}

Keywords: porous material, cellular concrete, internal condensation, numerical calculation, heat, moisture transfer

多孔質材料，気泡コンクリート，内部結露，数值計算，熱，水分移動

\section{1. 序}

建築壁体の内部で結露水が生じると、それは種々の問 題を引き起こすことは周知の事実であるが、多孔質材 料の内部で結露水が生ずる過程の水分移動現象は複雑 で、その解析にはかなりの困難がともなう。これまで結 露再蒸発過程における多孔質材料内の水分移動を定量的 に解析した研究は、コンクリート系材料を用いた Kooi の研究1)、松本・鐘井の研究 2 や水畑の研究 ${ }^{3}$ があり、軟 質䋐維板を用いた池田の研究4)等がある。文献 1)では、 Philip-de Vries の水分移動理論に基づき、片面の断湿さ れた気泡コンクリート材料内における水分挙動の解析が 行われている。温度分布は水分移動とは独立に計算され ている。文献2)においては非発泡系のセメント系多孔体 （軽量コンクリート）を用いて蒸発過程と結露過程につ いて、文献 1)では扱われなかった熱・水分の同時移動を 考虑した計算方法によって解析がなされている。また、 文献3）においては気泡コンク、リート材料について、熱.
水分同時移動の基礎式に基づき内部結露面の変動が数値 計算され、内部含水率分布の予測計算法が示された。文 献 4)においては軟質繊維板について、含水率をポテン シャルとする熟・水分同時移動方程式を用いた結露過程 の材料内含水率の変動解析が行われている。しかしなが ら、建築材料の熱・水分物性值は同種の材料でさえ製品 によるバラツキがあるので、できるだけ多くの材料に関 して実験を行い、その定量的解析をすることが必要と考 えられる。本報では、近年壁体材料によく用いられる気 泡コンクリートの一種を用いて、片面が断湿された壁体 材料の内部に結露が生ずる過程及びその結露水が再蒸発 する過程における内部含水率測定実験を゙行い、その実験 条件における材料内部含水率を熱・水分同時移動方程式 を用いて予測計算し、その結果を実測値と比較検討する とともに熱・水分同時移動方程式による解析の妥当性を 検討している。さらに熟・水分同時移動方程式中のパラ メーターや実験条件の違いが、材料内含水率の計算結果
* 三重大学工学部建築学科 助手·工修

** 三重大学工学部建築学科 ·教授・工博
Research Assoc., Dept. of Architecture, Faculty of Engineering, Mie University, M. Eng.

Prof., Dept. of Architecture, Faculty of Engineering, Mie University, Dr. Eng. 


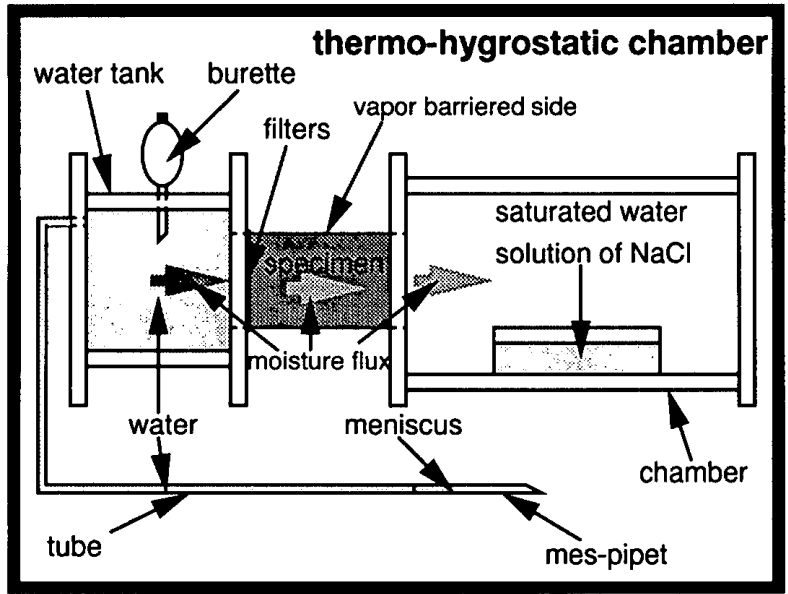

図 $1: D_{\theta}$ 実験装置概要

に与える影響について考察し、結露水が建築壁体材料中 に蓄積されていく現象について定量的な把握を行なって いる。

\section{2. 水分移動の理論}

多孔質性材料内部の水分移動は、材料内部に結露が生 じるような高含水の状態においては含水率と温度に支配 される。そして、重力及び吸着熟の影響が無視しうる場 合には、一次元の熱流及び水分流に対して熱水分移動方 程式は次のように表される5゙。

$$
\begin{aligned}
\frac{\partial \theta}{\partial t} & =\frac{\partial}{\partial x}\left(D_{\theta} \frac{\partial \theta}{\partial x}\right)+\frac{\partial}{\partial x}\left(D_{T} \frac{\partial T}{\partial x}\right) \\
c \gamma \frac{\partial T}{\partial t} & =\frac{\partial}{\partial x}\left(\lambda_{\theta} \frac{\partial T}{\partial x}\right)
\end{aligned}
$$

壁体材料の片面が室内空気にさらされ、他方の面が断湿 されている場合、境界条件は室内側表面においては

$$
\begin{aligned}
\frac{\alpha^{\prime}}{\gamma_{w}}\left(P_{i}-P_{s}\right) & =-D_{\theta} \frac{\partial \theta}{\partial x}-D_{T} \frac{\partial T}{\partial x} \\
\alpha\left(T_{i}-T_{s}\right) & =-\lambda_{\theta} \frac{\partial T}{\partial x}
\end{aligned}
$$

断湿面においては

$$
\begin{gathered}
-D_{\theta} \frac{\partial \theta}{\partial x}-D_{T} \frac{\partial T}{\partial x}=0 \\
T=T_{d}
\end{gathered}
$$

と表される。

\section{3. 各種物性值}

対象とした壁体材料は気泡コンクリートの一種（イト

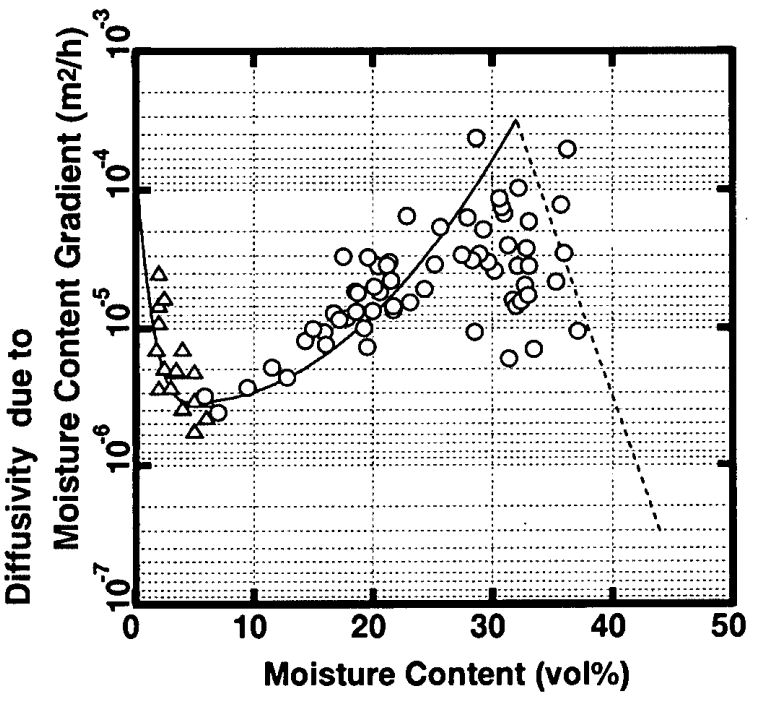

図 2 : 含水率勾配による水分拡散係数

ン、日本イトン社製 $650 \mathrm{~kg} / \mathrm{m}^{3}$ ) であり、それらの水分 移動に係わる物性値について以下に述べる。

含水率勾配に対する水分拡散係数 $\left(D_{\theta}\right)$

材料内に拉いて温度差がなく、材料内を流れる水分流 が一次元の定常状態にある場合、次式が成立する。

$$
\frac{q_{w}}{\gamma_{w}}=-D_{\theta} \frac{\partial \theta}{\partial x}
$$

従って、材料の一端に水分を供給し、他端から蒸発させ、 流れが定常になった時の水分流量 $q_{w}$ 、およびその直後 の材料の分割によって含水率分布、含水率勾配 $\frac{\partial \theta}{\partial x}$ を 求め、 $D_{\theta}$ を決定することができる。 $D_{\theta}$ の測定実験装置 の概要を図 1 に示す。側面をビニルテープによって断湿 された長さ $40 \mathrm{~mm}$ 、断面積 $30 \mathrm{~mm} \times 40 \mathrm{~mm}$ の試料の一 端を水槽の水に接触させ、他端を一定温湿度に保たれて いるチャンバー内に開放した。メスピペット内の水のメ ニスカスの移動量を読みとることにより、試料への流入 水分量が測定され、その時間的変化がほほ一定になった 時の流入水分量から $q_{w}$ を求めた。その後、試料を装置 から取り外し、マルチバンドソーで厚さ方向（水分流の 方向）に数等分し、それら小片の湿潤重量を測定した。 全小片を絶乾して乾燥重量、厚さを求めて各小片の平均 含水率を算出し各小片の中心位置の含水率とみなした。 定常時の流入水分量および試料内含水率勾配より求めら れた水分拡散係数 $D_{\theta}$ と含水率の関係を図 2 に示す。 印は測定值を表し、 $\triangle$ 印は文献 1)に報告されている測 定値を表す。また実線はそれらに对する近似曲線を表し ている。これらの值は $\mathrm{Kooi}^{1}{ }^{1)}$ 松本・鎿井 ${ }^{2)}$ の測定値と も良く一致している。およそ $32 \mathrm{vol} \%$ 以下の低水率の領 域では測定值のバラッキは少なく、ほぼ一定の範囲に分 布しているが、高含水率の領域においてはバラツキが大 きく、分布の範囲を特定するのは難しくなっている。約 


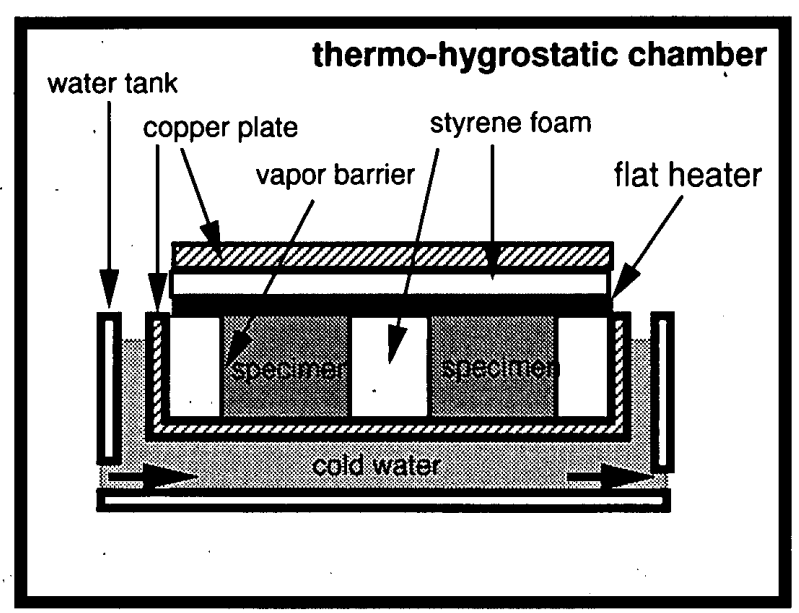

図 $3 ：$ 温度勾配係数測定実倹概要

$32 \mathrm{vol} \%$ 以上の含水率域では、この材料の特性として材 料内の気泡中に空気がエントラップされるために含水率 が約 $32 \mathrm{vol} \%$ 以上で吸湿能力が激減し $D_{\theta}$ の值が下がる 傾向を示すと思われる1)。この領域では、測定值から近 似式を求めることは難しく、後述する結露·再蒸発過程 の計算值が一致するように、適当な直線を仮定して近似 式を求めている。それを図2では破線で示した。

温度勾配に対する水分拡散係数 $\left(D_{T}\right)$

材料内を流れる水分流量が一次元の定常状態にあり、 水分流量が 0 の場合には次式が成立する。

$$
0=-D_{\theta} \frac{\partial \theta}{\partial x}-D_{T} \frac{\partial T}{\partial x}
$$

よって

$$
\frac{D_{T}}{D_{\theta}}=-\frac{\nabla \theta}{\nabla T} \equiv \varepsilon
$$

となる。ここに、 $\varepsilon$ は温度勾配係数である。従って試料 を全面断湿して、その両端に温度差を設け、十分長い時 間の後に熱・水分の移動が定常状態に達すれば、その時 の含水率勾配と温度勾配から $\varepsilon$ が求められる。温度勾配 係数 $\varepsilon$ の測定装置を図 3 に示す。ある含水率を持つ同一 条件の厚さ $30 \mathrm{~mm}$ 、大きさ $45 \mathrm{~mm} \times 45 \mathrm{~mm}$ の試料を多数 用意し、全面をビニルテープによって断湿する。側面を 発泡スチロールにより断熱し、試料の上面を面ヒーター で加熱、底面を冷水で冷却し、試料内に鉛直方向に熱流 を生じさせる。時間経過とともに、随時一つの試料を装 置からはずし、鉛直方向に数片の小片に切断し、それら の重量から含水率分布を算出する。また、特定の試料に は内部に熟電対が鉛直方向に数個埋め込まれており、試 料内の温度分布が測定されている。試料内の含水率分布 が定常に至った時の試料内含水率分布と温度分布から含 水率勾配と温度勾配が算出でき (9) 式からをを求めるこ とが出来る。図 4 は $\varepsilon$ と含水率の関係を示し、○印は測

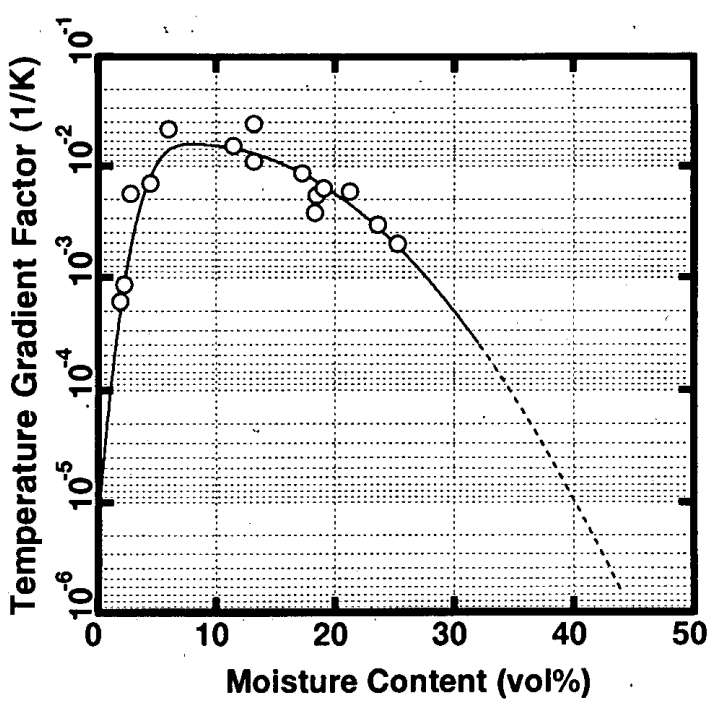

図 4 : 温度勾配係数

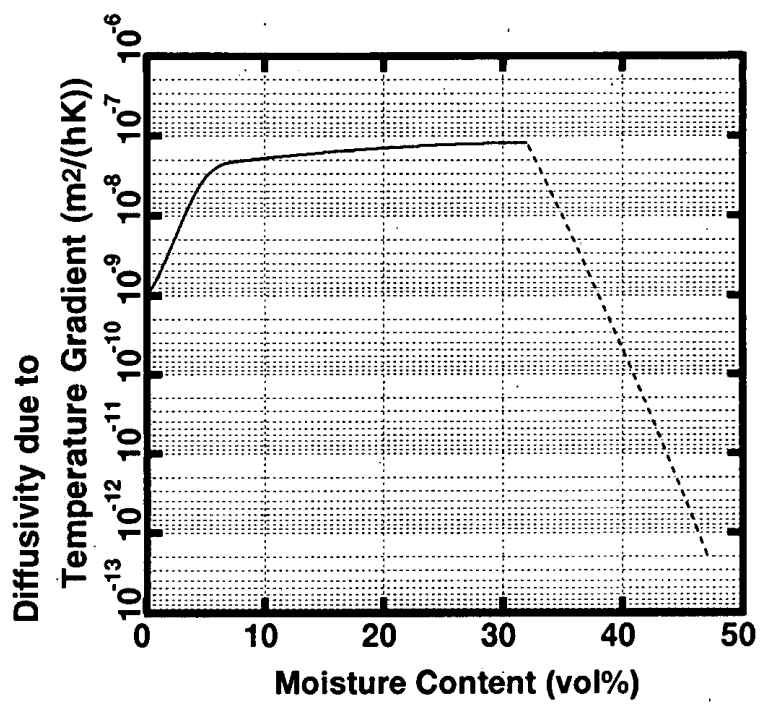

图 5 : 温度勾配による水分拡散係数

定值、実線はそれらに対する近似曲線を表している。測 定值は近似曲線からほほ一定の範囲に分布している。 と $D_{\theta}$ が既知ならば、次式によって温度勾配による水分 拡散係数 $D_{T}$ が求められる。

$$
D_{T}=\varepsilon \cdot D_{\theta}
$$

図 5 は、図 3 の含水率勾配に上る水分拡散係数 $D_{\theta}$ の近 似式と図 4 の温度勾配係数 $\varepsilon$ の近似式より(10) 式を用 いて求められた温度勾配に対する水分拡散係数 $D_{T}$ の含 水率による変化を示す。図 4 、図 5 において約 $32 \mathrm{vol} \%$ 以 上の $\varepsilon$ および $D_{T}$ は外挿值であるので破線で示されて いる。

\section{熱伝導率}

湿った材料の熱伝導率は、一般に含水率の増加と共に 大きくなることはよく知られている。定常法による測定 


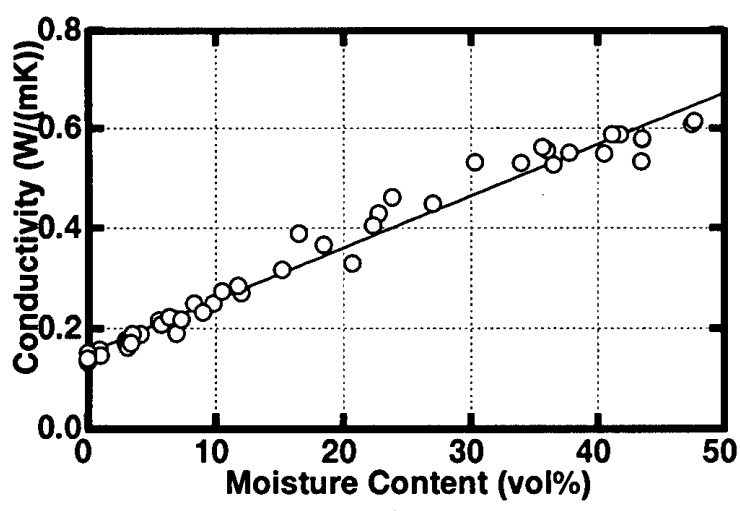

図 6 : 熱伝導率

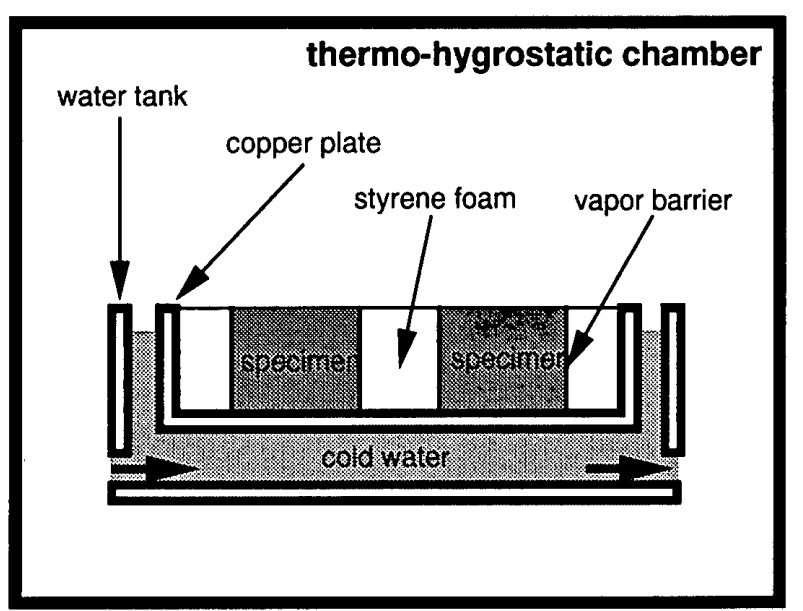

図 $8 ：$ 結露・再蒸発実験装置概要

は測定時間が長く、湿った材料の測定においては測定中 に含水率分布が変化するので適当ではない。ここではプ ローブの熱線の温度上昇の時間的割合から 5 分程度の 短時間で測定可能な非定常法によって様々な含水率を持 つ気泡コンクリートの熱伝導率を測定した。非定常法に よって測定された気泡コンクリートの熟伝導率と含水率 との関係を図 6 に示す。図中の○印は測定値、実線は測 定值の近似直線である。測定値は近似直線からほほ一定 の範囲に分布している。

\section{平衡含水率}

$\mathrm{LiCl} 、 \mathrm{MgCl}_{2} \cdot 6 \mathrm{H}_{2} \mathrm{O} 、 \mathrm{Mg}\left(\mathrm{NO}_{3}\right)_{2} \cdot 6 \mathrm{H}_{2} \mathrm{O} 、 \mathrm{NaCl} 、$ $\mathrm{KNO}_{3}$ の 5 種類の塩の飽和水溶液を入れた気温 $20{ }^{\circ} \mathrm{C} の$ ガラス容器中に気泡コンクリートの小片の試料を長時間 設置し、各試料の重量変化がほとんどなくなった時点で の重量と、その試料の絶乾重量とから平衡含水率を求め た。その結果を図 7 に示す。図中の○印は測定值、実線 は測定值の近似曲線を示す。測定值は近似曲線からほほ 一定の範囲に分布している。

\section{4. 結露・再蒸発過程の実験}

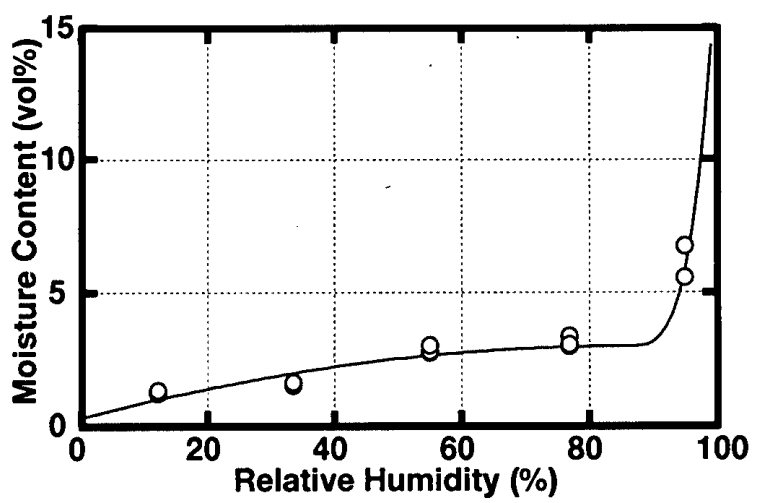

図 7 : 平衡含水率曲線

片面が断湿された壁体材料の内部に結露が生ずる過程 及びその結露水が再蒸発する過程の水分挙動を把握する ため、結露・再蒸発過程の内部含水率の時間的変動を測 定する実験を行った。

\section{実験概要}

片面が断湿された材料内部に結露させるために図 8 に 示すように恒温恒湿室に置かれた水槽上面の銅板上に試 料を設置し、試料底面を水槽の冷水で冷却した。試料(厚 さ $30 \mathrm{~mm}$ 、大きさ $70 \mathrm{~mm} \times 50 \mathrm{~mm})$ として平均含水率測 定用 3 体と含水率分布測定用に多数の材料を用意した。 熱流及び水分流が一次元になるように試料の側面および 底面をビニルテープにより断湿し、側面は発泡スチロー ルで断熟した。結露過程では室内温湿度は $25{ }^{\circ} \mathrm{C} 、 72 \%$ に設定し、試料底面温㹥全期間 $15{ }^{\circ} \mathrm{C}$ を保った。この過 程では室内空気中の水分が試料内に流入し、試料内部の 含水率が上昇する。試料の重量変化が無くなった後、試 料を再蒸発させるために室内温湿度を $25{ }^{\circ} \mathrm{C} 、 45 \%$ に設 定し、実験を続けた。再蒸発過程では試料内の水分が放 出され、試料内の含水率が減少する。平均含水率測定用 の試料は一定時間間隔で重量を測定した。また任意の時 期に含水率分布測定用試料の一つを装置から取り外し、 厚さ方向に $5 \mathrm{~mm}$ 幅で 6 個の試料片に切断した。それ らの湿潤重量と乾燥重量を測定し、それぞれの含水率を 算出し、厚さ方向（鉛直方向）の含水率分布を求めた。 実験結果

試料の含水率変化および実験室内温湿度、試料底面温 の結露過程および再蒸発過程の時間的経過を図 9 に示す。 図中の 3 本の実線は平均含水率測定用試料 ( 3 個) の平 均含水率の時間的変動測定値を表す。また、○印は含水 率分布測定用試料の全体湿潤重量から算出した平均含水 率から求められた測定値を表す。両者は比較的よく一致 しており、これらの試料の内部水分は、ほほ同様の挙動 を示していることが分かる。

図 10 は材料内の含水率分布の時間的変動を表してい る。図中の○〜のの印は、含水率分布測定用試料の切断 された小片の含水率測定值を示している。 


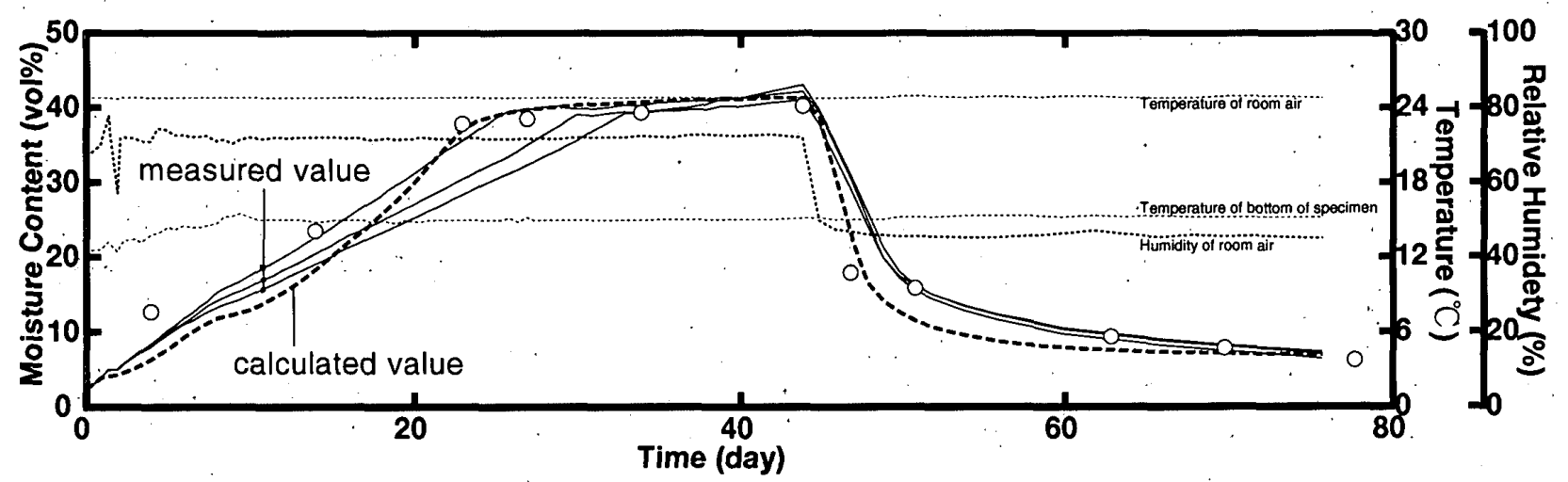

図 $9 ：$ 結露・再蒸発過程の平均含水率の変動

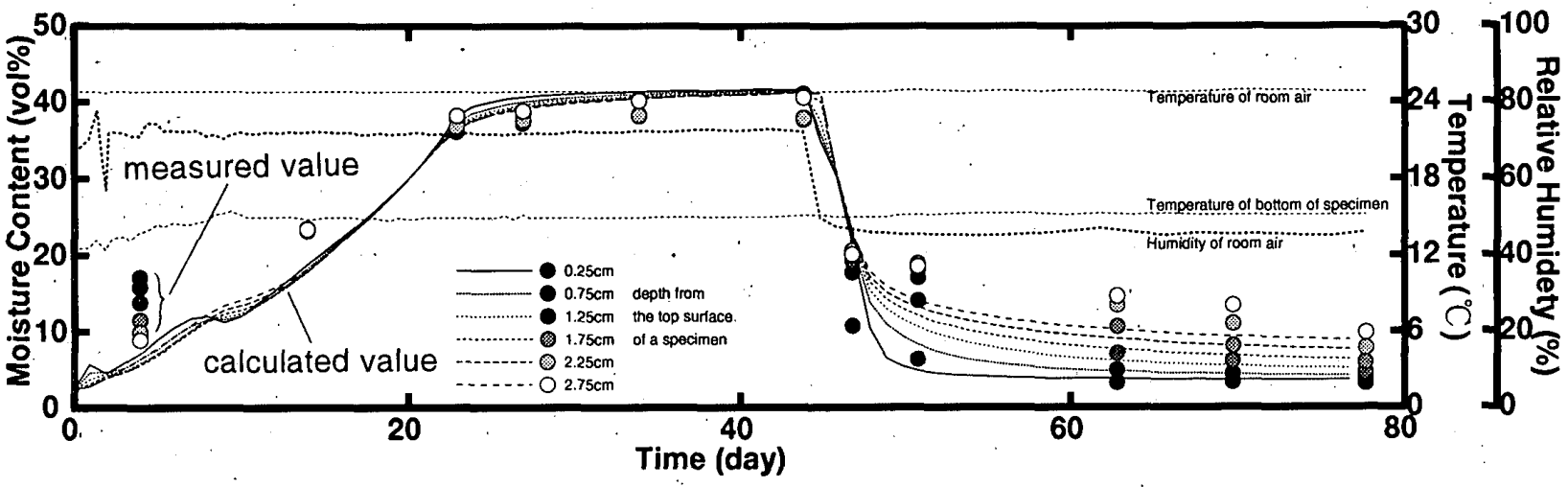

図 10 : 結露・再蒸発過程の含水率分布の变動

実験の開始後しばらくの間、恒温恒湿室の加湿器の不 調のため湿度の制御がうまくできず、結露過程の初期に おいては平均含水率および含水率分布の変動の起伏が激 しいが、その後恒温恒湿室内はほは一定の温湿度を保つ ことができた。試料の平均含水率の変動は、結露過程で は含水率が約 40vol\%でほほ定常となり、再蒸発過程に おいては約 7vol\%で下降が少なくなっている。

\section{5. 結露 ·再蒸発過程の解析}

\section{実験值と計算值}

結露・再蒸発過程における熱 · 水分同時移動方程式の 数値計算は Crank-Nicolson 型 implicit 差分法によって 行われ、分割時間 $\Delta t$ は $1 / 20 \sim 1 / 60$ 時間、分割寸法 $\Delta x$ は $0.0025 \mathrm{~m}$ (分割数 12）とした。室内側表面水蒸気圧 $p_{s}$ は試料の平衡含水率曲線から表面含水率 $\theta_{s}$ に応じた 相対湿度と表面温 $T_{s}$ とから算出した。

結露・再蒸発実験条件下において (1) (6).式を用い て計算された試料内平均含水率の時間経過が図 9 の破線 で示されている。また、図10の実線および破線は試料 を鉛直方向に $6 つ の$ 層に分割した時の各層の中心位置に 拈ける含水率の計算值を表しており、切断された含水率 分布測定用試料の各小片の平均含水率にほほ対応してい る。
図 9 において平均含水率変動の計算值は結露・再蒸発 両過程ともに実測值とかなりょく一致している。しかし 結露過程 10 日から 25 日の平均含水率上昇期において 平均含水率の上昇勾配が計算值よりも実験值の方が若干 緩やかであり、また、再蒸発過程初期の平均含水率下降 期においても同様に下降勾配が計算値よりも実験值の方 が若干緩やかである。これは数值計算に用いた、試料表 面近傍の熱伝達率、試料表面近傍の湿気伝達率、試料の $D_{\theta}$ 、試料の平衡含水率、室空気の温湿度の設定值が、実 験における実際の值と多少の相違がある事に起因してい ると考えられる。また、試料の平衡含水率と $D_{\theta}$ の值は ともに吸湿過程のものを用いており、それらの放湿過程 におけるヒステリシスの影響を無視していること、温湿 度測定の機器による測定誤差が温度では $\pm 0.5{ }^{\circ} \mathrm{C}$ 、湿度 では土 $1 \%$ 程度あることなどの原因が考えられる。図 10 に扔いて、材料内の含水率分布変動は実験值と計算值は かなり良く一致している。各層の含水率の絶対値に相違 はあるが、結露過程初期において実験値と計算値はとも に試料表面付近の含水率が高く、試料断湿面側の含水率 は低い。結露定常期に入ると各層の含水率の差が小さく なる。再蒸発過程では試料表面付近の含水率が低く、試 料底面付近の含水率が高くなっている。

\section{感度解析}

材料の熱・水分物性値のバラツキを考虑して計算式中 


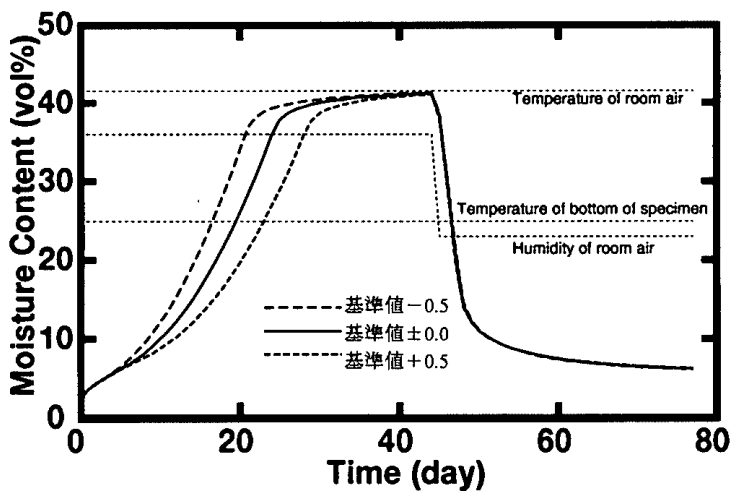

図 11 : 熱伝達率の平均含水率に対する影響

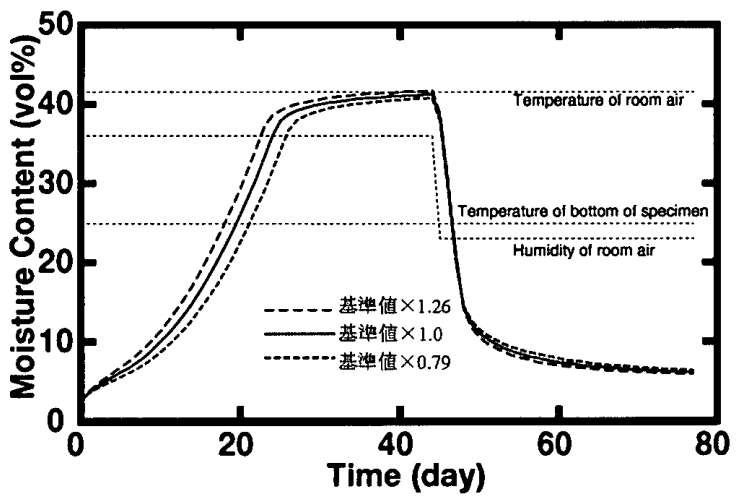

図 $13: D_{\theta}$ の平均含水率に対する影響

の温湿度条件及び材料物性値の変化が試料内含水率計算 に与える影響について検討するため、実験時に設定され た室内温湿度、試料底面温度および材料物性值を基準值 として平均含水率の計算を行い、含水率変動に対する感 度解析を行った。設定された温湿度条件は室温 $25^{\circ} \mathrm{C} \cdot$ 試 料底面温度 $14{ }^{\circ} \mathrm{C}$ 一定、結露過程湿度 $72 \%$ - 再蒸発過程 $45 \%$ 一定である。

図 11 は試料の室内側表面伝達層における熱伝達率 $\alpha$ の設定值を基準值 (7.8) に対して \pm 0.5 変化させて計算 された平均含水率変動を示している。結露過程では含水 率の上昇期に最大 $\pm 8 \mathrm{vol} \%$ 程度の含水率の差異が生じる が、結露平衡時および再蒸発時の含水率の差は極僅少で ある。

図 12 は試料の室内側表面伝達層における湿気伝達 率 $\alpha^{\prime}$ の設定値を基準值 $\left(0.18 \times 10^{-3}\right)$ の 2.0 倍および 0.5 倍にして計算された含水率変動を表している。結露過程 の含水率上昇期において平均含水率の上昇勾配に差が生 じ、再蒸発過程初期においても平均含水率の下降勾配に 差がみられる。湿気伝達率が大きいほど平均含水率の上 昇・下降勾配が大きい。

図 13 は $D_{\theta}$ の設定值を、全含水率域にわたって基 準值 (図 2 の近似曲線の値) の $1.26\left(=10^{0.1}\right)$ 倍および $0.79\left(=10^{-0.1}\right)$ 倍にして計算された平均含水率変動を示 す。 $D_{\theta}$ を 1.26 倍および 0.79 倍した曲線は、図 2 の実験

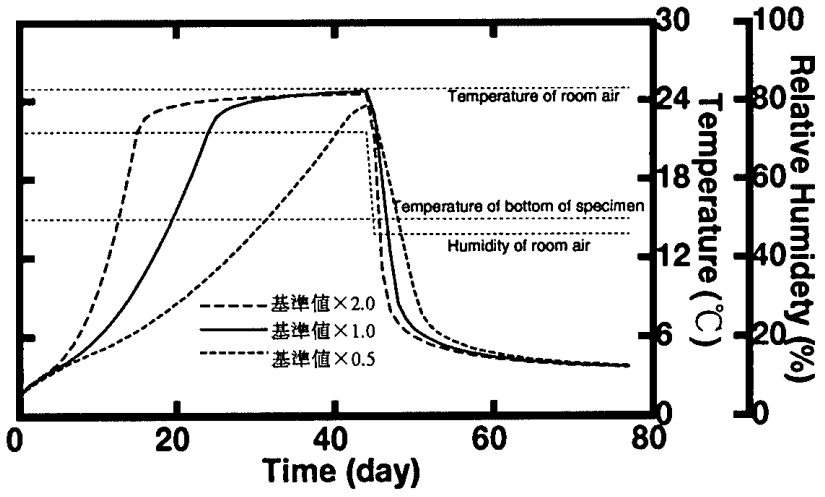

図12: 湿気伝達率の平均含水率に対する影響

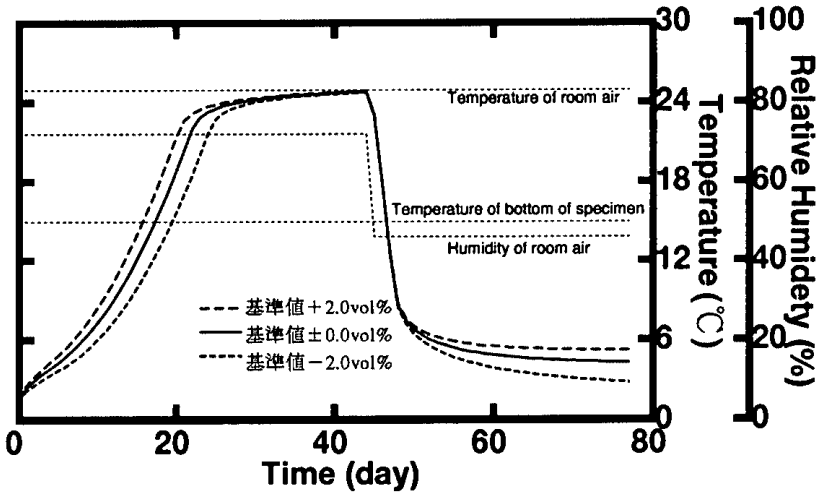

図 14 : 平衡含水率の平均含水率に対する影響

值の分布する範囲の上下限を意味する。結露過程の含水 率に最大 $\pm 5 \mathrm{vol} \%$ 程度の差異が生じるが、平衡時およ び再蒸発過程の含水率の差は約 $1 \mathrm{vol} \%$ ある。

図 14 は基準の平衡含水率曲線（図 7 の曲線）を $\pm 2.0 \mathrm{vol} \%$ 上下に平行移動した場合の平均含水率変動の計 算結果を示す。再蒸発過程の定常期において、平衡含水 率曲線を上に平行移動させた場合に含水率は $3 \sim 4 \mathrm{vol} \%$ 上 昇する。

図 15 は、試料底面温度の設定值を基準値 $\left(14^{\circ} \mathrm{C}\right)$ に 対して $\pm 0.1{ }^{\circ} \mathrm{C}$ 変化させた場合の平均含水率変動の計算 結果を表している。どちらの場合も含水率上昇期におい て、基準設定值の場合と比較して 5 6 vol\% の含水率の 差が生じ、試料の底面温度を高くすると含水率が低くな り、底面温度を低くすると含水率は高くなる。

また、試料底面温度を基準設定値 $\left(14^{\circ} \mathrm{C}\right)$ のままにし、 室温の設定値を基準値 $\left(25^{\circ} \mathrm{C}\right)$ に対して $\pm 0.1{ }^{\circ} \mathrm{C}$ 変化さ せた場合の平均含水率変動の計算も行ったが、その結果 はほとんど図 15 と同様の結果となった。室温を高くす ると平均含水率は高くなり、室温を低くすると平均含水 率は低くなる。したがって試料内の温度差が同じであれ ば、平均含水率はほほ同じ挙動を示す。

図 16 は室内湿度の設定值を基準值 (結露過程 $72 \%$ 、 再蒸発過程 $45 \%$ ) に対して $\pm 0.5 \%$ 変化させた場合の平 均含水率変動の計算結果を示している。結露過程の含水 


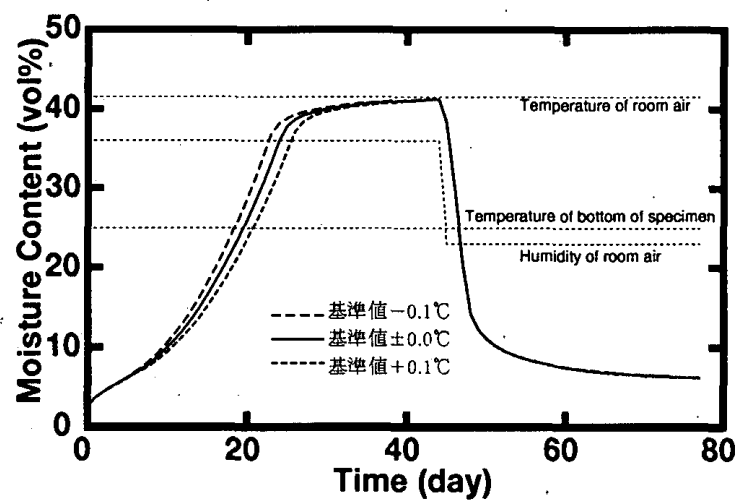

図 15 : 試料底面温度の平均含水率に対する影響

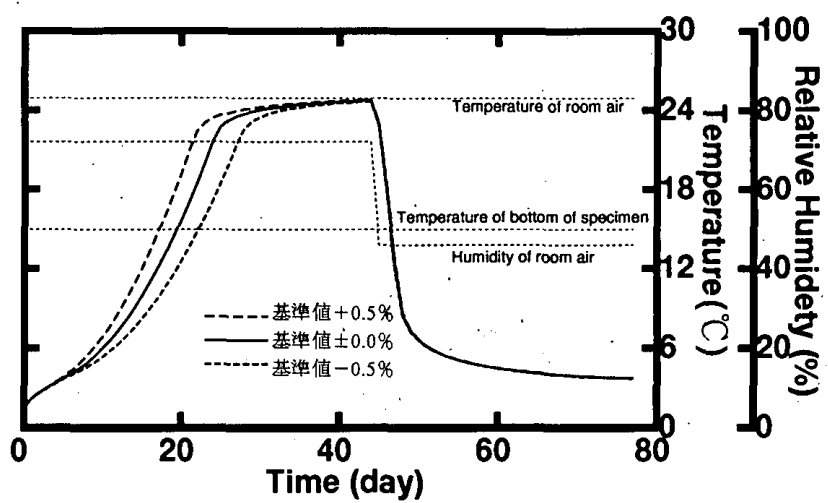

図 16 : 室内湿度の平均含水率に対する影㖺

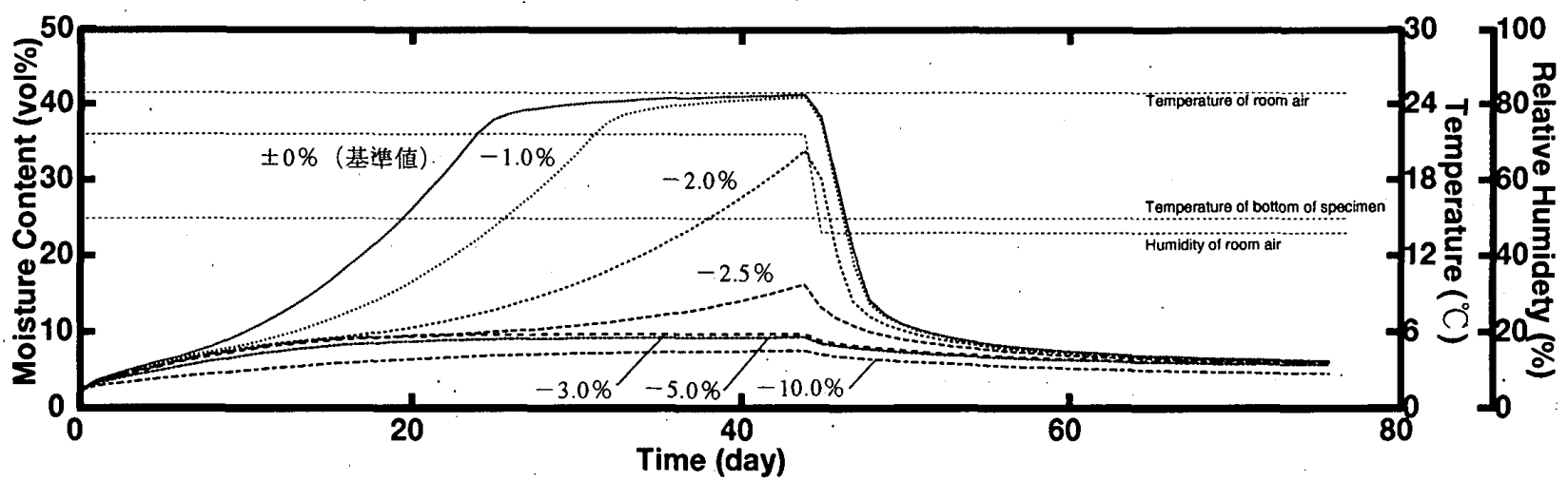

図 17 : 室内湿度の平均含水率に対する影響

率上昇期において $0.5 \%$ 変化させた場合は、基準値の 場合に対して最大約 $6 \mathrm{vol} \%$ 前後の含水率の差が生じて おり、湿度において $\pm 0.5 \%$ の変化が平均含水率にかなり の影響を与えることになる。

\section{含水率変動と含水率領域}

図 17 は、室内湿度の設定值を基準値 (結露過程 $72 \%$ 、 再蒸発過程 $45 \%$ ) に対して $\pm 0.0 \%$ から $-10.0 \%$ 変化させ た場合の平均含水率挙動を示している。相対湿度が（基 準值-10.0）\%から（基準值-2.5）\%に変化させた場合の 平均含水率の挙動は、含水率の差にして約 $10 \mathrm{vol} \%$ 範囲 に分布しているのに対して、（基準値-2.5）\%から（基 準值士0.0）\%に変化ざせた場合は含水率差が $25 \mathrm{vol} \%$ 以 上の範囲に分布する。また、相対湿度を（基準值-10.0） \%から（基準値-3.0）\%に変化させた場合のそれぞれの 平均含水率挙動は結露定常時に約 $10 \mathrm{vol} \%$ 付近で平衡し ている。

図 18 は、試料底面温度の設定值を基準值 $\left(14{ }^{\circ} \mathrm{C}\right) に$ 対して $\pm 0.0{ }^{\circ} \mathrm{C}$ から $+4.0{ }^{\circ} \mathrm{C}$ 変化させた場合の平均含水率 挙動を示している。試料底面温度を（基準值+1.0） ${ }^{\circ} \mathrm{C}$

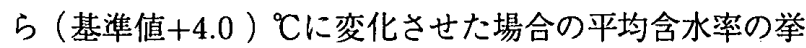
動は、含水率の差にしておよそ 15 vol\%の範囲に分布し ているのに対して、（基準値士0.0） ${ }^{\circ} \mathrm{C}$ 放（基準值+1.0 ) ${ }^{\circ} \mathrm{C}$ に変化させた場合の平均含水率挙動は含水率差 25 vol\%以上の範囲に分布する。また、試料底面温度を(基
準值+4.0） ${ }^{\circ} \mathrm{C}$ から（基準値+1.5） ${ }^{\circ} \mathrm{C}$ 変化させた場合の それぞれの平均含水率挙動は結露定常時に約 $10 \mathrm{vol} \%$ 付 近で平衡している。

図 19 は、室温の設定値を基準值 $\left(25^{\circ} \mathrm{C}\right)$ に対して -4.0 ${ }^{\circ} \mathrm{C}$ から $0.0{ }^{\circ} \mathrm{C}$ に変化させた場合の平均含水率挙動を示 している。室温を（基準值-4.0） ${ }^{\circ} \mathrm{C}$ 放（基準值-1.0） ${ }^{\circ} \mathrm{C} に$ 変化させた場合の平均含水率の挙動は、含水率の差 にしておよそ 15 vol\%の範囲に分布しているのに対して、 （基準值 $\pm 0.0 ｛ }^{\circ} \mathrm{C}$ から（基準値-1.0） ${ }^{\circ} \mathrm{C}$ に変化させた 場合の平均含水率挙動は含水率差 $25 \mathrm{vol} \%$ 以上の範囲に 分布する。また、室温を（基準値-1.5） ${ }^{\circ} \mathrm{C}$ から（基準值 -4.0) ${ }^{\circ} \mathrm{C} に$ 変化させた場合のそれぞれの平均含水率挙動 は結露定常時に約 $10 \mathrm{vol} \%$ 付近で平衡している。

これらから、温湿度条件が平均含水率変動の計算結果 に及はす影響は、温湿度の変化に対して非線形的であり、 その影響の大きさは平均含水率の上昇が的 $10 \mathrm{vol} \%$ を 越えるか否かで挙動が異なることが分かる。

図 2 において含水率勾配による水分拡散係数が極小と なる含水率はおよそ $10 \mathrm{vol} \%$ ありり、図 4 においても温 度勾配係数が最大となる含水率は的 $10 \mathrm{vol} \%$ あるる。こ の含水率は試料の含水状態が蒸気支配と液水支配との境 界に相当する状態と考えられている1)。この試料に関し ては、含水状態が液水支配の状態になっている場合、試 料がさらされている室空気の僅かの温湿度の上昇によっ 


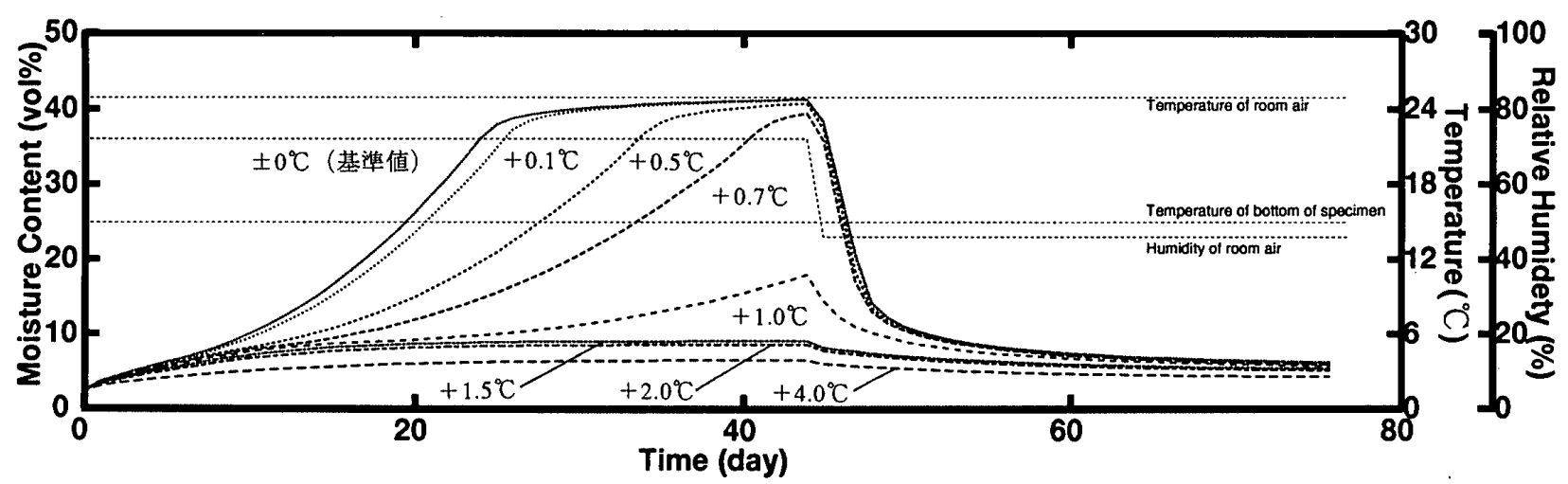

図 $18 ：$ 試料底面温度の平均含水率に対する影響

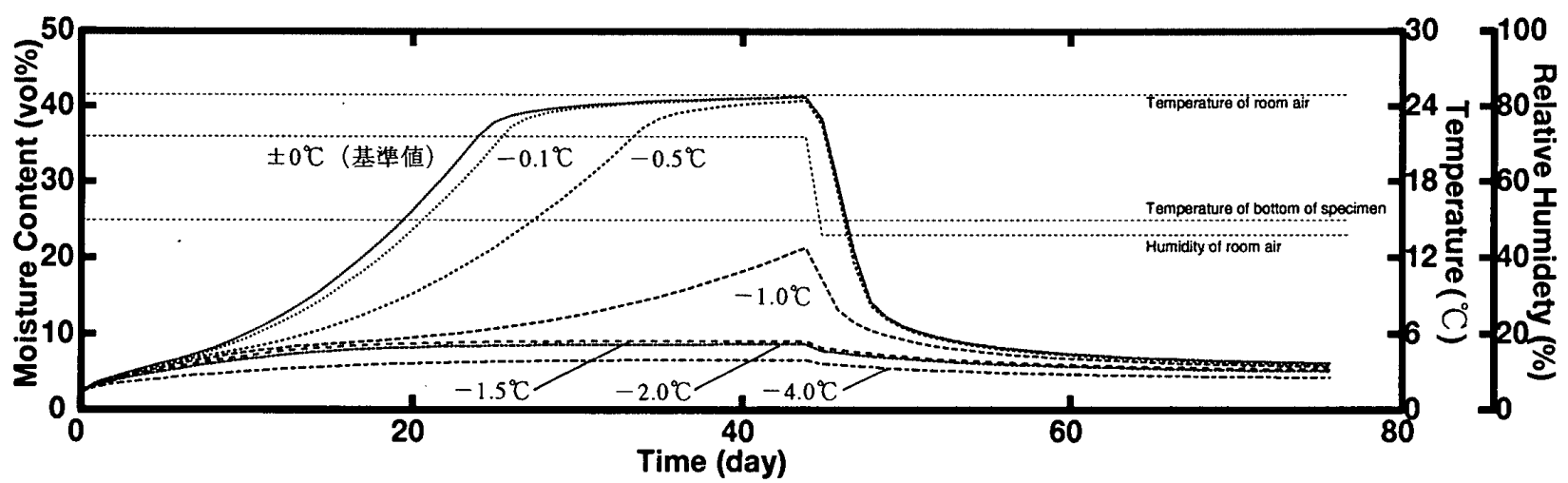

図 19 : 室温の平均含水率に対する影響

て、試料の含水率が急激に上昇する可能性をはらんでい ることを示している。逆に、材料の平均含水率が蒸気支 配の状態ならば、室空気の温湿度の多少の変化に対して も、材料中の含水率の変動は僅かであり、材料を低い含 水状態に保つことが出来ることを示している。

\section{6. 結語}

片面を断湿した気泡コンクリート材料内に内部結露が 生じ、その後再蒸発する場合の材料内部含水率測定実験 を行い、その実験条件における内部含水率分布を熱・水 分同時移動方程式によって数值計算し、計算結果と実験 結果を比較検討した。以下にその結果をまとめる。

1. 気泡コンクリートの熱・水分物性値を測定した結 果、図 2 及び図 4 〜図 7 に示す特性を持つことが示 され、この材料に関する物性值のおよその分布範囲 が把握された。

2. 熱・水分同時移動方程式による計算値と実験値はか なり良く一致する。重力及び吸着熱の影響を無視し 得ると仮定された熱水分同時移動方程式の、本実験 における結露・再蒸発過程に対する適用の妥当性が 示された。

3. 材料の熱・水分物性值のバラッキを考虑して試料が
曝されている室内空気の温湿度条件および材料物性 值が内部含水率変動に与える影響を明らかにした。

4. 温湿度条件に関しては、試料の含水状態によってそ の感度は異なり、低含水率の状態では曝露空気の温 湿度の影響は僅かだが、高含水率状態においては、 温湿度の僅かの変動でも、試料内の平均含水率に大 きく影響を及ほすことを明らかにした。

本報で扱った気泡コンクリートに関しては、10 vol\% 前後の含水率を境界として、含水率がそれ以上になると 急激に平均含水率が上昇する。この值が試料の含水率を 低い状態に保持するための目安とすることができると思 われる。今後の課題としては、高含水状態になりがちな 外壁や屋根等に用いられる多孔質性材料内部の熱・水分 特性の把握、一般の多孔質性材料に対する本解析方法の 適用に関する検討、多層壁体への応用などが挙げられる。 
[ 記号]

\begin{tabular}{|c|c|c|}
\hline$\theta$ & 体皘含水率 & [vol\%] \\
\hline$T$ & 温度 & [C] \\
\hline$D_{\theta}$ & 含水率勾配による水分拡散係数 & {$\left[\mathrm{m}^{2} / \mathrm{h}\right]$} \\
\hline$D_{T}$ & 温度勾配による水分拡散係数 & {$\left[\mathrm{m}^{2} /(\mathrm{h} \cdot \mathrm{K})\right]$} \\
\hline$c$ & 材料の比熱 & {$[\mathrm{W} \cdot \mathrm{h} /(\mathrm{kg} \cdot \mathrm{K})]$} \\
\hline$\gamma$ & 材料の比重量 & {$\left[\mathrm{kg} / \mathrm{m}^{3}\right]$} \\
\hline$\gamma_{w}$ & 水の比重量 $\left(=10^{3}\right)$ & {$\left[\mathrm{kg} / \mathrm{m}^{3}\right]$} \\
\hline$\lambda_{\theta}$ & 熟伝導率 & {$[\mathrm{W} /(\mathrm{m} \cdot \mathrm{K})]$} \\
\hline$\alpha$ & 熟伝達率 (=7.8) & {$\left[\mathrm{W} /\left(\mathrm{m}^{2} \cdot \mathrm{K}\right)\right]$} \\
\hline$T_{i}$ & 室内温度 & [C] \\
\hline$T_{s}$ & 試料表面温度 & [C] \\
\hline$\alpha^{\prime}$ & 湿気伝達率 $\left(=0.18 \times 10^{-3}\right)$ & {$\left[\mathrm{kg} /\left(\mathrm{m}^{2} \cdot \mathrm{h} \cdot \mathrm{Pa}\right)\right]$} \\
\hline$P_{i}$ & 室内水蒸気庄 & {$[\mathrm{Pa}]$} \\
\hline$P_{s}$ & 試料表面水蒸気圧 & {$[\mathrm{Pa}]$} \\
\hline$T_{d}$ & 断湿面温度 & {$\left[{ }^{\circ} \mathrm{C}\right]$} \\
\hline$q_{w}$ & 単位面積当りの水分流量 & {$\left[\mathrm{kg} /\left(\mathrm{m}^{2} \cdot \mathrm{h}\right)\right]$} \\
\hline$\varepsilon$ & 温度勾配俰数 & {$[1 / \mathrm{K}]$} \\
\hline 添字 $v$ & 蒸気 & \\
\hline
\end{tabular}

\section{[本論文に関連する既発表論文]}

- 水烟雅行、他：建築材料の含水率測定、日本建筑学会東 海支部研究報告集第 27 号、pp285-288 (1989)

- 水沜智之、他：建築材料の温度勾配による水分拡散係数 の測定、日本建策学会大会学術講演梗概集 D 環境工学、 pp1117-1118 (1990)

- 寺島貴根、他:壁体材料中の結露-再蒸発過程の解析、日本 建築学会大会学術講演梗概集 D 環境工学、pp1119-1120 (1990)
- 寺島貴根、他:建筑材料の結露·再蒸発過程の実験と計算、 日本建筑学会東海支部研究報告集第 30 号、 pp 325-328 (1992)

- 寺島貴根、他：多孔質性材料における結露再蒸発過程の 数值解析について(温湿度条件および材料物性値の測定 精度が材料内含水率計算に与える影響)、日本建築学会 大会学術講演梗概集 D 環境工学、pp929-930 (1992)

- 寺島貴根、他:壁体材料の結露·再蒸発過程に対寸る数值解 析 (含水率計算に対する温湿度および材料物性值の影響) 、日本建築学会東海支部研究報告集第 31 号、pp333-336 (1993)

[文献]

1) Kooi J.V.D. : Moisture Transport in Cellular Concrete Roofs. Diss. T.H.Eindhoven, Uitgeverij Waltman Delft (1971)

2）松本衛・鉃井、他：セメント系多孔質建築材料の結露、 乾燥過程の実験とその解析、日本建築学会論文報告集第 353 号、pp11-20 (1985)

3) 水畑雅行：内部結露面变動の数值解析、日本建築学会論 文報告集第 300 号、pp95-104 (1980)

4）池田哲朗：結露障害防止に関する基礎的研究、学位論文 (1979)

5）松本衛：建築壁体における熱・水分同時移動および氷分 蓄皘に関する研究、学位論文 (1978)

（1995年 1月10日原稿受理，1995年 5 月 1 日採用決定） 